\title{
Дети для тувинцев: изменения отношения в социокультурных трансформациях
}

\author{
Чимиза К. Ламажаа \\ Тувинский государственный университет, Российская Федерация
}

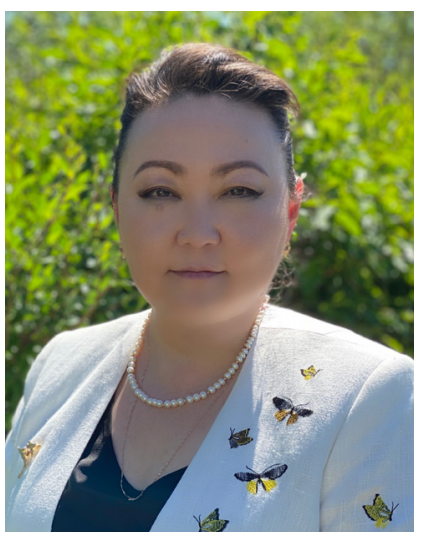

В статье анализируется проблема трансформации отношения взрослых к детям в тувинском обществе на фоне общих социальных изменений в XX и XXI вв. Историкокультурологическое исследование проведено с привлечением методов социальной и культурной антропологии. Отношение к детям рассматривается как часть культуры детства - детской субкультуры. Актуальность исследования связана с явным кризисом современного родительства тувинцев.

В традиционном тувинском обществе культура детства развивалась в условиях, которое ему обеспечивало общество с родовым укладом жизни. Дети были в центре внимания, были окружены заботой, воспитанием и родовое сообщество гарантировало их защиту. Эта традиционная модель, которая формировалась на протяжении всего культурогенеза, позволяла в том числе развиваться и сантиментам в отношении детей - воспеванию, восхищению, любованию, умилению.

В советское время дети перестали быть только объектом попечения родителей, которых контролировало родовое сообщество. Как и во всей советской стране, они стали объектами и государственной политики. Влияние родителей, а уж тем более - широкого круга родственников было уменьшено и даже оттеснено, в том числе системой образования и воспитания. Учебновоспитательная программа базировалась на общей политике. Само родительство перестало быть столь же важным для культуры детства как раньше. Дети стали общественным ресурсом и неизвестной «переменной» для родителей в плане их будущего для семьи.

В постсоветское время государство потеряло главенствующую позицию регулятора. Новыми факторами, определяющими особенности культуры детства, выступают теперь вестернизационные тенденции, технологические новации, которые появились с глобализацией. В этих условиях в отношении взрослых к детям появились новые, дополнительные мотивы - общие, лишенные тувинской этнической составляющей. Увеличенный период инфантильности молодежи, молодых родителей приводит к безответственности по отношению к детям, желанию жить на детские пособия и материнский капитал. Другая форма отношения родителей-тувинцев к детям - гиперопека, гиперзабота. Значительная часть тувинцев сделала нормой обеспечение ребенка всем необходимым не только в детстве, но и в последующем взрослении.

Ключевые слова: тувинцы; родство; дети; культура детства

Подготовлено при финансовой поддержке Российского научного фонда в рамках научного проекта «Тезаурус этнической культуры в XXI веке: проблемы исследования и сохранения (на примере тувинской культуры)» (грант № 21-18-00246).

Для цитирования:

Ламажаа Ч. К. Дети для тувинцев: изменения отношения в социокультурных трансформациях // Новые исследования Тувы. 2021, № 4. С. 57-75. DOI: https://www.doi.org/10.25178/nit.2021.4.5

Ламажаа Чимиза Кудер-ооловна - доктор философских наук, заведующая лабораторией этнологии и лингвокультурологии Тувинского государственного университета. Адрес: 667000, Россия, г. Кызыл, ул. Монгуша Сата, д. 9, лит. В, каб. 107. Тел.: +7 (916) 413-33-85. Эл. адрес: lamazhaа@tuva.asia

LAMAZHAA, Chimiza Kuder-oolovna, Doctor of Philosophy, Head, Laboratory of Ethnology and Linguoculturology, Tuvan State University. Postal address: Office 107, Letter B, 9 Mongusha Sata St., 667000 Kyzyl, Russian Federation. Tel.: +7 (916) 413-33-85. E-mail: lamazhaa@tuva.asia 


\title{
Tuvans' Views on Children: Changes of the Attitudes in Socio-cultural Transformations
}

\author{
Chimiza K. Lamazhaa \\ Tuvan State University, Russian Federation
}

\begin{abstract}
The article analyzes the issue of the transformation of adults' attitude to children in Tuvan society amid general social changes in the 20th and 21st centuries. The historical and cultural research was carried out with the use of methods of social and cultural anthropology. The attitude towards children is considered as part of the culture of childhood, a children's subculture. The relevance of the study is due to the overt crisis of modern parenting among the Tuvans.

In the traditional Tuvan society, the culture of childhood was developing under conditions provided by the society with the clan system of living. Children were the focus of attention, they were given every care and support. The tribal community guaranteed their protection. This traditional model was formed throughout the entire cultural genesis. It allowed, among other things, the development of sentiments towards children - praising, fascination, admiration, and affection.

In Soviet times, children ceased to be only the object of parental care. Parents were controlled by the tribal community. As in all corners of the Soviet country, children became the objects of state policy. The influence of parents and especially of a wide range of relatives was reduced and even pushed aside in particular by the education and upbringing system. The teaching and educational program was based on a general policy. Parenthood itself ceased to be as important for the culture of childhood as it used to be. Children became a public resource and an unknown "variable" for parents in terms of a future for their family.

In the post-Soviet period, the state has lost its superiority as a regulator. Westernization trends and technological innovations that have appeared in the course of globalization are now new factors that determine the features of the culture of childhood. In these conditions, new additional motives in the attitude of adults towards children have emerged - they are common and devoid of the Tuvan ethnic constituent. The increased period of infantilism of the youth and young parents leads to irresponsibility towards children, the desire to live on child benefits and maternity capital. Another form of Tuvan parents' attitude to children is hyperprotection and hypercare. A significant part of the Tuvans have made it the norm to provide the child with everything necessary not only in childhood, but also in subsequent adulthood.
\end{abstract}

Keywords: Tuvans; kinship; children; culture of childhood

\section{Financing}

The article was prepared with financial support from the Russian Science Foundation within the framework of the research project "Thesaurus of Ethnic Culture in the 21st Century: Problems of Study and Preservation (The Case of Tuvan Culture)" (grant No. 21-18-00246).

For citation:

Lamazhaa Ch. K. Deti dlia tuvintsev: izmeneniia otnosheniia v sotsiokul'turnykh transformatsiia [Tuvans' Views on Children: Changes of the Attitudes in Socio-cultural Transformations]. New Research of Tuva, 2021, no. 4, pp. 57-75. (In Russ.). DOI: https://www.doi.org/10.25178/nit.2021.4.5

\section{Введение}

Уруглар, уруг-дарыг - дети - считались одной из главных ценностей тувинской традиционной культуры, как и других культур, которым, по определению одного из авторитетных российских культурологов С. Н. Иконниковой, характерна любовь к детям, в отличие от культур с боязнью детей и тех, где есть традиции избавления от них (Иконникова, 2018: 57¹). В культурах первого типа (более распространенных сегодня) дети окружены обожанием, заботой. Умилению детям, их пестованию посвящены целые разделы тувинского фольклора; традиции воспитания детей тувинцами составили значительное число трудов этнографов, культурологов, педагогов; материнство воспевалось в профессиональной художественной культуре - литературе, живописи XX века. Любовь тувинцев к детям, забота о детях (Салчак К., Салчак П., 2016: 167) - казалось, составляли один из столпов культуры, которого невозможно было поколебать.

${ }^{1}$ С.Н.Иконникова использует для этого термины соответственно - «инфантофилия», «инфантофобия» и «инфантоцид», подразумевая типологию культур по отношению к детям (infant - младенец). Однако, в связи с тем, что термины содержат определенную негативную коннотацию и первый из них - «инфантофилия» - связывается в СМИ с нездоровым сексуальным влечением к детям (синонимично слову «педофилия»), я не буду их употреблять. 
Тем не менее, социальные и культурные трансформации тувинского общества в XX - начале XXI вв. отразились и на этой сфере семейных отношений, и в целом социокультурной жизни. Особенно в последние годы общественность Тувы неоднократно потрясают случаи, когда выпивающие матери намеренно или ненамеренно убивали своих детей, оставляли их в опасности, или избавлялись от них, выбрасывая их на улицу. Случаи единичны, но тем не менее СМИ могут сообщать о них по 2-3 раза в год и каждый раз это вызывает волну возмущений в обществе. В целом отказы от детей привели к росту числа сирот и обострению проблемы сиротства в республике. И все это разворачивается на фоне продолжающейся динамики рождаемости в Туве, одной из самых высоких в стране. Для старшего поколения тувинцев подобная ситуация кажется немыслимой, в общественном дискурсе республики много непонимания и рефреном звучит вопрос «Как тувинцы дошли до такого?» Это активизировало исследования тувиноведением традиций воспитания тувинцами детей, в том числе и реферативного характера, прежде всего для того, чтобы придать публикациям рекомендательный характер (Сундуй, 2009, 2015; Иргит, 2013; Кара-оол, 2015а; Доржу, Корчевская, 2015; Хурен-оол, 2018; Ежова, 2019 и др.).

Среди научных работ также присутствуют и исследования измененных семейных традиций, современного состояния культуры детства, сиротства (Дыртык-оол, 2018; Кисель, 2016; Корчевская, 2016; Данчай-оол, Даваа, 2021 и др.). Но, на мой взгляд, мы можем говорить об общих трансформациях отношения тувинцев к детям (не только связанных с отдельными вопиющими случаями), а также изучать причины трансформаций. Обращение к этим вопросам нуждается и в изменении научных подходов, и ракурсов рассмотрения - всего того, что в тувиноведении пробивается, к сожалению, с огромном трудом.

Поэтому целью данной статьи будет анализ трансформации отношения тувинцев к детям на фоне общих социальных изменений XX и XXI вв. Историко-культурологическое исследование проведено с привлечением методов социальной и культурной антропологии, учитывающих типические биографии отдельных людей, то есть как и любое другое children's studies, по определению разворачивающееся как междисциплинарное (Сальникова, 2007: 17). При этом отношение к детям рассматривается как часть культуры детства, то есть детской субкультуры, взаимодействующей со взрослой культурой, а также с другими социальными институтами. Этническая составляющая нашего предмета исследования заключается в формах взаимоотношений родителей и детей, которые подчинялись тувинским традициям. То есть ценностные основания культуры детства тувинцев понимаются в тесной связи с особенностями этнической культуры и общими социокультурными процессами современного тувинского общества.

Для решения поставленной цели будут последовательно решены несколько задач: проведен обзор литературы по различным исследованиям детства и культуры детства тувинцев, условно выделены периоды и последовательно рассмотрены особенности трансформационных изменений отношения тувинцев к детям на протяжении XX века и в начале XXI в.

Источниковой базой исследования выступают научная литература, отдельные тексты художественной литературы и фольклора, материалы авторских наблюдений за последние 20 лет в Туве, сообщения СМИ.

\section{Обзор литературы}

В целом, проблематику детства в культуре тувинцев, присутствующую в научной литературе, и на которую в том числе я опираюсь, можно рассматривать по группам: этнографические, этнопедагогические, филологические, социально-демографические и культурологические.

В этнографических работах анализируются традиции детства в народной культуре тувинцев (традиции рождения, традиции усыновления, традиции воспитания в семье, игры детей, занятия детей, обязанности детей, детский фольклор, взаимоотношения родителей и детей, приметы, связанные с детьми и пр.). О том, чем у тувинцев занимались дети, писали многие путешественники, первые исследователи тувинской культуры и быта (см. обзор: Дыртык-оол, 2015). Но специально тему детей в традициях тувинцев поднимали в своих работах, например, Л. П. Потапов в монографии «Очерки народного быта тувинцев», где описывал детские обряды, начиная от рождения (Потапов, 1969: 266-278). Чем занимались дети в хозяйственной жизни аала упоминал в своих публикациях С. И. Вайнштейн (Вайнштейн, 1991). В книгах М. Б. Кенин-Лопсана «Традиционная культура тувинцев» (Кенин-Лопсан, 2006) и «Тыва чаңчыл» («Тувинские традиции») (Кенин-Лопсан, 2017), есть разделы, 
посвященные детям (Кенин-Лопсан, 2006: 113-117; 2017: 178-108). Последующие работы и их основные идеи были рассмотрены в моем обзоре исследований о том, какое место занимает ребенок в тувинской традиционной культуре (Ламажаа, 2015).

В этнопедагогических работах обсуждаются вопросы народной педагогики и воспитания детей, прежде всего традиционной (периодизация детских возрастов, педагогические установки, приемы воспитания детей, особенности обучения методами народной педагогики и пр.). В советское время выходила монография четы тувинских педагогов К. Б. и Л. П. Салчаков (Салчак К., Салчак Л., 1984; переиздано: Салчак К., Салчак Л., 2016). В. П. Дьяконова посвятила традициям воспитания детей у тувинцев в сравнении с аналогичными традициями теленгитов статью (Дьяконова, 1988) в специальном сборнике, в котором были собраны исследования этнографии детства у народов Сибири (Традиционное воспитание ... , 1988). Основательно была проработана тема традиций детского воспитания у тувинцев в монографии этнопедагогов Г. Н. Волкова, К. Б. Салчака и А. С. Шаалы (Волков, Салчак, Шаалы, 2009). Этнопедагогические традиции уже более широкого культурного ареала - тувинско-монгольского - были представлены в монографии Г. Д. Сундуй (Сундуй, 2009). В последующем вышли новые статьи исследователей по отдельным аспектам проблем воспитания (Иргит, 2013; Хурен-оол, 2018; Куулар, 2019 и др.).

Вопросы развития этнопедагогических исследований, традиций национальной школы в целом легли в основу работы Института развития национальной школы при Министерстве образования и науки Республики Тыва, история которого восходит к лаборатории «Билиг» при Кызылском государственном педагогическом институте, созданной в 1992 г. На сайте института (http://irnsh.ru/) paзмещено значительное число научных публикаций и методических разработок.

Отдельным направлением в этнопедагогических работах стали публикации об особенностях обучения детей-тувинцев, об учете этноспецифики из менталитета, языковых особенностей (Салчак, 2009; Мирошниченко, Донгак, 2020; Ликтан, Монгуш, 2021 и др.).

В традициях воспитания и ухода за детьми особое место занимал фольклор, связанный с детьми. Речь идет о колыбельных, сказках для детей, песнях, частушках и пр. Все эти вопросы составляют содержание особого раздела фольклора - детского фольклора ${ }^{1}$, который нашел также отражение в книге Г. Н. Курбатского (Курбатский, 2001), был исследован в статьях и диссертации Ч. К. Кара-оол (Кара-оол, 2013, 2014, 2015abc). Обрядовый фольклор детского цикла тувинцев Китая представлены также в статьях и в особом разделе монографии Ж. М. Юша (Юша, 2006, 2018: 158-209). К этому же филологическому направлению исследований можно отнести и работы исследователей, посвященные обрядам, а также традициям именования детей, в том числе чтобы оградить их, защитить, уберечь от несчастий (Сувандии, 2011; Кара-оол, 2019; Ооржак, Бавуу-Сюрюн, 2020). Не буду уже приводить сведения о многочисленных тувинских сказках, предназначенных для детей, пословиц и поговорок, касающихся детей, которые выходили в свет в самых разных изданиях с начала XX в. (см.: Чамзырын, 2013 и др.).

Социально-демографические исследования, в которых дети рассматриваются как члены семей, социальная группа (дети и взрослые, дети как учащиеся школ, дети разных социальных слоев, сироты), стали развиваться уже со второй половины ХХ в. В монографии «Молодежь Тувы. Социальный портрет», подготовленной по итогам комплексного исследования целого ряда научных центров по изучению молодого поколения советской республике, есть разделы, посвященные и новым поколениям детей (Молодежь Тувы. ..., 1988). В другом итоговом издании этносоциологов Г. С. Гончаровой и Л. Я. Савельева - монографии «Семейно-брачные отношения у народов Сибири: проблемы, тенденции, перспективы» (Гончарова, Савельева, 2004), в разделе, посвященном семьям Республики Тыва, авторы рассматривают не только состав семей, включающий количество детей, но и влияние родителей на браки детей (там же: $173-222)$.

В последние годы появились публикации исследователей по традициям усыновления тувинцами детей-сирот (Доржу, Корчевская, 2015; Корчевская, 2016 и др.), прямо обращенные к остросоциальной проблеме сиротства и обсуждающие традиции тувинцев по усыновлению детей именно с этой позиции.

\footnotetext{
${ }^{1}$ Матпаадыр: Произведения для детей / сост., авт. предисл. и коммент. С. М. Орус-оол, Р. С. Чакар. Кызыл : Тувинское книжное издательство, 1991. 268 с.; Матпаадыр: сборник детского фольклора / сост. С. М. Орус-оол. Кызыл : Детский литературный сайт «Радуга Тувы», 2021. 312 с.
} 
В целом тенденции тувиноведения идут в общем русле российской науки, но с традиционным опозданием. В отечественной историографии с конца 1970-х гг. стала оформляться история детства благодаря знакомству ученых с классическим трудом Ф. Арьеса «Ребенок и семейная жизнь при старом порядке» (переводное издание: Арьес, 1999). За редким исключением (Кон, 1988), до 1990-х гг. большая часть исследований детства оставалась в рамках возрастной психологии, педагогики и вопросов охраны материнства и детства (Ромашова, 2013: 108). Сегодня проблематика детства активно развивается в целом ряде направлений: например в этнографии детства (Комарова, 2014); детство стало рассматриваться и шире - как социально-философский (Разинкова, 2021) и как историкокультурный феномен (Конструируя детское ..., 2011). Особый интерес представляет исследование А. А. Сальниковой детства XX в., в котором также представлена обширная историография работ (Сальникова, 2007).

В этой связи следует приветствовать появление в тувиноведении культурологических исследований, среди которых назову интересные публикации Г. Д. Сундуй и М. О. Дыртык-оол. Уже упомянутая монография Г. Д. Сундуй, при общей этнопедагогической направленности, тем не менее содержит и представление о детстве как автономной реальности (Сундуй, 2009). И автор продолжает свои изыскания в этом русле (Сундуй, 2015 и др.). Правда все же коллега акцентирует свое внимание на традиционной культуре детства. М. О. Дыртык-оол, помимо того, что обобщила разрозненную информацию наблюдателей, путешественников рубежа XIX-XX вв. о традицияХ родовспоможения и ухода за детьми у тувинцев (Дыртык-оол, 2015), исследует как менялись традиции социализации детей тувинцев в условиях, когда само общество переходило на оседлый образ жизни (Дыртык-оол, 2018).

Отмечу, что подавляющее число работ посвящено культуре детства глазами взрослых. Самих детских голос в работах почти нет, за редким исключением. К числу таких работ можно отчасти отнести психологическое исследование Е. Л. Иргит, которая провела опрос среди школьников средней школы сумона Арыг-Узюнский Улуг-Хемского района Тувы (Иргит, 2013). Автор выявляла положительные и отрицательные образы отца по мнению мальчиков и девочек.

Из новых подходов к теме культуры детства отдельно упомяну и интересную статью В. А. Киселя «Мир детей в столице Тувы» (Кисель, 2016). Опираясь на методы визуальной антропологии, прилагая много фотографий, автор представил целый спектр детских игровых площадок, которые были замечены им в самых разных районах столицы Тувы - Кызыле. При этом особое внимание исследователя привлекли площадки с декоративной деревянной скульптурой с персонажами из национальных сказок.

Таким образом, отмечу, что культура детства тувинцев, в том числе и отношение взрослых к детям, по большей части исследованы прежде всего в прошлом - в традиционной культуре тувинцев. Целостное изучение культуры детства тувинцев, включающее и изменения, и спектр отдельных вопросов, нам еще предстоит.

\section{Дети в традиционном обществе тувинщев}

Любовь к детям у тувинцев, как и у многих других народов, забота о них, воспитание в традиционной культуре всегда были неразрывно связаны со всей системой культурных и социальных норм. Однако в XX веке и далее это соотношение менялось. Рассмотрим как.

В традиционном тувинском обществе культура детства развивалась в условиях, которое ему обеспечивало, как правильно пишет Г. Д. Сундуй, общество с родовым укладом жизни (Сундуй, 2015). В этой системе все общественные нормы поощряли, во-первых, само наличие детей, во-вторых, правильное воспитание детей.

Считалось, что тувинцы должны иметь детей, которые были будущими помощниками по хозяйству, были продолжателями рода. Многодетные семьи имели много будущих работников, это обеспечивало процветание рода. И в общественных нормах присутствовали правила и помощи многодетным семьям (например, М. Б. Кенин-Лопсан пишет про обычай делиться дойной коровой богатым с бедными многодетными семьями, см.: Кенин-Лопсан, 2006: 60). В случаях, если семьи были бездетными, если у пар не удавалось вырастить детей (дети рождались, но умирали), если рождались двойняшки (Л. П. Потапов пишет о том, что разнополых близнецов следовало воспитывать в разных семьях, см. Потапов, 1969: 273-274), был развит обычай уруг азыраар - прием, усыновление, воспитание детей родственников и других людей. Многодетные отдавали детей бездетным на воспитание. Причем, Г. Д. Сундуй 


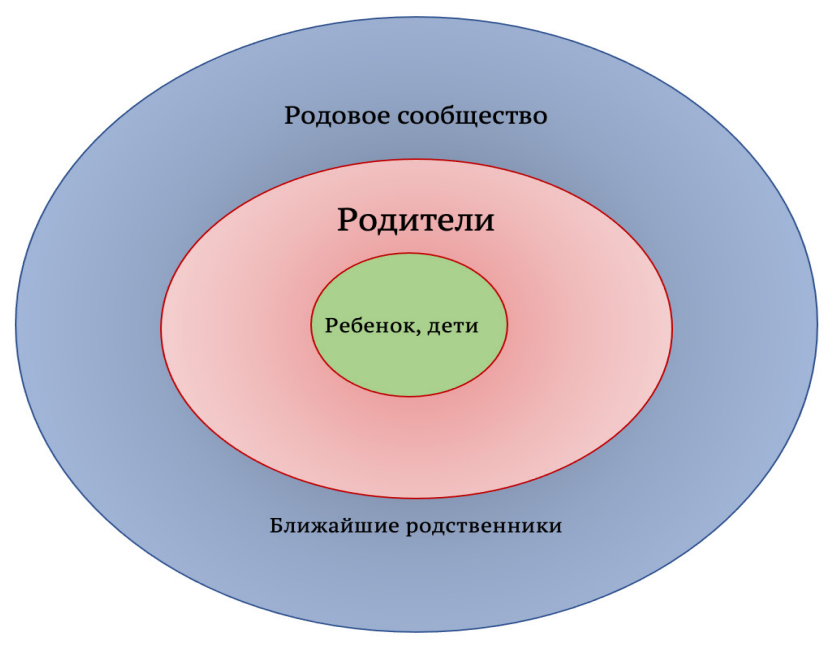

Puc. 1. Место детей в структуре родового сообщества.

Fig. 1. Children's place in the structure of the tribal community.

отмечает несколько видов устройства детей: пожизненное, временное и вовсе символическое (Сундуй, 2015: 28). Во всех случаях имелись правила обращения с детьми, поведения родных и приемных родителей.

В целом место детей в таком обществе было определенным - в центре (см. puc. 1). Традиции родового сообщества диктовали что и как следует делать, чтобы не допускать отсутствия у детей воспитателей. Детей не отнимали, например, у незамужних матерей (которые сами жили в родительском аале, то есть возможность воспитывать детей имелась), рационально распределяли осиротевших по семьям, определяя отдельных детей из многодетных - тем, кто тоже может растить их и пр.

Тем самым родовое сообщество гарантировало, что дети защищены и окружены вниманием (Сундуй, 2009: 126-128). Они сразу приучаются жить в том трудовом мире, который они и будут поддерживать далее. Это обязывало родителей правильно воспитывать детей, приучать их к труду (Хурен-оол, 2018). Интересен в этой связи сюжет из монографии Г. Д. Сундуй, которая отметила обычаи, связанные с принуждением молодых матерей к принятию и уходу за ребенком (Сундуй, 2009: 147-148). Если окружающие замечали охлаждение отношения матери к ребенку, то опытная женщина проводила с ней воспитательную беседу - ласково, но убедительно. Если это не помогало, то прибегали к более жесткой форме - к запугиванию матери: оставляли ее одну с ребенком в условиях, когда малышу могла грозить опасность (вблизи с табуном коней, около выхода скота из кажаа (кошары), чтобы в женщине проснулись охранные инстинкты.

Даже советская педагогическая литература, называя идеи кочевой культуры «наивным гуманизмом», отмечая и их недостатки, тем не менее усматривала «прогрессивные» традиции воспитания тувинцами детей (Салчак К., Салчак Л., 2016: 169). Г. Д. Сундуй тувинскую систему воспитания предлагает именовать Ужурлар дизии - «Сводом законов, правил, установок жизни» (Сундуй, 2009: 69-78), в который, по ее словам, входили правила отношения родителей к детям и наоборот - детей к родителям, а также система поддержки широкого круга родственников.

В целом эта традиционная модель также в литература называется культурой репродуктивного поведения, в которой создание семьи, рождение детей, многодетность поддерживались сразу на нескольких уровнях: социальном (обряды, праздники, законы), экономическом (подарки, отдельное жилище, выделение скота) и технологическом (условия, способствующие вынашиванию, рождению и взращиванию ребенка) уровнях (Андреева, 2015: 14).

Эта традиционная модель, которая формировалась на протяжении всего культурогенеза, позволяла в том числе развиваться и сантиментам в отношении детей - воспеванию, восхищению, любованию, умилению. 


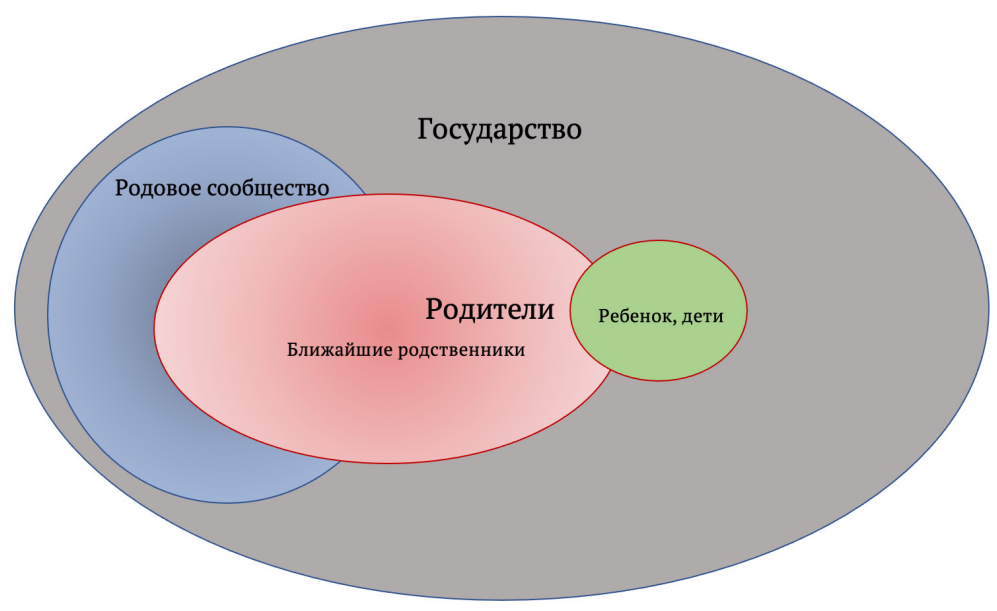

Рис. 2. Модель места детей в структуре советского общества.

Fig. 2. The model of children's place in the structure of Soviet society.

\section{Дети тувинцев в $\mathrm{XX}$ веке}

Вхождение Тувы в цивилизационное поле России, принятие советской внутренней политики, а затем и вступление в состав советского государства, реализация советских идеалов, изменило социальную структуру тувинского общества, многие культурные нормы общества (Ламажаа, 2011: 55-67). Дети перестали быть только объектом попечения родителей, которых контролировало родовое сообщество. Как и во всей советской стране, они стали объектами и государственной политики. Культура детства стала определяться и государством: где и чему учиться детям, как им следует одеваться, о чем мечтать, чем и кем гордиться (см. рис. 2). Об этом также пишет М. О. Дыртык-оол (Дыртык-оол, 2018: 141).

Влияние родителей, а уж тем более - широкого круга родственников было уменьшено и даже оттеснено. Это происходило разными способами, но прежде всего формированием системы образования.

Первые тувинские начальные школы появились в 1926 г. в Тувинской Народной Республике, политика которой во многом копировала советскую (Монгуш, 2006: 18). В 1933 г. был определен план культурного строительства, который определял структуру народного образования страны (там же: 21). В 1935-1939 гг. кочевьях аратов заработали летние школы с сокращенной программой начальной школы. Это делалось для приближения школы к жилью животноводов (Аранчын, 1982: 220-221). Но кочевой образ жизни диктовал необходимость и создания школ-интернатов, где дети могли бы учиться и жить в течение всего учебного года. К моменту вхождения ТНР в состав СССР в 1944 г. система народного образования уже сложилась и включала в себя начальные, семилетние, средние школы, а также средние специальные учебные заведения и сеть центров по ликвидации неграмотности (Монгуш, 2006: 23). Школьная система становилась одновременно и с ломкой традиций кочевого образа жизни тувинцев, их седентаризацией.

Семья и дети также вошли в поле социальной политики государства. Были открыты детские сады для детей аратов, при ведомствах, в колхозах, совхозах. В советской Туве учебно-воспитательная программа базировалась на общей политике, в которой «жизненные ориентиры для детей, идеалы поведения, нормы повседневной жизнедеятельности транслировались “сверху” путем создания привлекательных образов прошлого и настоящего, на которые следовало равняться советскому ребенку» (Ашенова, 2018: 15).

Тувинские дети, как и дети по всей стране, стали получать совершенно иной опыт и знания, чем был у их родителей, чем был в их быту. Характерны воспоминания педагога В. Б. Монгуш, Заслуженного работника образования Республики Тыва, школьное детство которой пришлось на 1940-1950-е гг.: 
«Каждое утро мама приводила меня в школу, открывшуюся в 1949 году в селе Малые Аянгаты за три километра от нашей осенней стоянки. Как только удалится, я от школы - бегом, домой. Пришлось ей сдавать меня из рук в руки башкы, учителю, Калгак-Хурену. Я, шестилетняя, была самой маленькой его ученицей. Остальные - от семи до шестнадцати лет. И все - в одном классе, подготовительном.

Четыре года Калгак-Хурен учил тому, что знал сам: счету, письму. Всё по-тувински. На пятый год приехала учительница русского языка Зоя Ивановна Павлова ...

Зою Ивановну мы поначалу побаивались. Башкы пришла на урок с длинной палочкой. Что она будет этой палочкой делать, неужели наказывать нас?

Потом поняли, что эта палочка-указка совсем не страшная. Зоя Ивановна писала на доске русские буквы, показывала на них указкой, а мы хором повторяли. Укажет на дверь, назовет ее, снова повторяем.

Ни она, ни мы ее толком не понимали, а переводить было некому....

Приносила яркие картинки, спрашивала, что это? Если знакомые животные, мы радовались, что можем ответить по-тувински: лошадь, корова, овца, собака. И она радовалась, называла их по-русски.

А как-то принесла картинку: какие-то разноцветные предметы. До сих пор они у меня перед глазами: арбуз, яблоко, огурец, помидор. Но тогда-то мы их в жизни не видели. Не можем понять, о чем она толкует.

Зоя Ивановна не сдается: приносит в класс круглое и красное на тарелочке. Говорит по слогам: по-ми-дор. Мы повторяем. А она разрезает свой наглядный материал и раздает всем в классе по кусочку. Угощайтесь, мол. До сих пор помню вкус первого своего помидора, мне он тогда не понравился. А одну девочку вырвало прямо в классе, потом другую, третью. Опять загрустила наша учительница, а нам так неловко было перед ней» ${ }^{1}$.

Культура детства тувинских ребятишек в таких условиях в конечном счете приобрела черты культуры советских детей, которых воспитывали в семье (подотчетной государству), но учили и социализировали прежде всего в специальных учреждениях. Соответственно у советских школьников появилась и своя особая повседневность, свои ритуальные практики, общение, мечты (Куприянов, 2018).

В этих условиях отношение тувинцев-родителей к детям поменяло формат. Разумеется, родители не перестали любить и растить детей. Но семья в таких условиях, как писал Арьес о введении школьной формы обучения для детей западной культуры, становится лишь пространством эмоциональной привязанности между супругами, между родителями и детьми, каковым не являлась ранее (Арьес, 1999: 10). А родовое сообщество и вовсе было почти разрушено и перестало контролировать родительство.

Как отмечают исследователи П. О. Омарова и 3. З. Гасанова, предполагалось, что с торжеством коммунизма семья переродится, а общество возьмет на себя максимум забот по воспитанию детей. Только в дошкольном возрасте, считалось, что дети должны жить в семье, а затем они должны воспитываться в общественных детских учреждениях, чтобы преодолеть вредное влияние семейного воспитание в результате целенаправленного формирования коммунистического мировоззрения (Омарова, Гасанова, 2008: 182). То есть родители потеряли традиционный контроль, призванный поддерживать связь поколений, привлекать детей к труду родителей, объединять их в одном хозяйственном деле. Новый контроль - государственный - подразумевал скорее разрывы связей, чтобы формировались люди иных ориентаций, иных стремлений. Общая проблематика школьного обучения детей была отмечена еще в труде Ф. Арьеса, который писал, что школа заменила практическое обучение «в людях», ребенок уже не смешивался со взрослыми и не постигал жизнь в непосредственном контакте с ними. Он был отделен от взрослых и помещен в своего рода карантин, предваряющий его выход в мир (Арьес, 1999: 10).

Тем самым и само родительство перестало быть столь же важным для культуры детства как раньше. Сами дети для родителей уже не представляли залог будущего рода, не рассматривались помощниками общего хозяйства, как раньше. Дети стали, помимо всего прочего, неизвестной «переменной». В кого вырастет ребенок, кем захочет стать, сколько средств надо готовить для его дальнейшей учебы и обустройства, уедет ли вообще сын или дочь в другую местность жить после учебы? Эти и другие вопросы стали новыми для тувинцев, как и для многих народов, традиционная жизнь которых оказалась в прошлом.

\footnotetext{
${ }^{1}$ Люди Центра Азии. Т. 6. Кызыл : ООО Редакция газеты «Центр Азии», 2018. С. 686.
} 


\section{Дети тувинцев в XXI веке}

Не удивительно, что когда само советское государство завершило свой исторический путь, то государственный контроль рухнул над всеми сферами общественной жизни, в том числе обеспечивавшими воспитание и защиту детства. После десятилетия духовного вакуума и ярко выраженных архаизационных тенденций в обществе 1990-х гг. (Ламажаa, 2013), мы в итоге можем наблюдать еще одну модель положения детей в социальном мире (puc. 3). При этом подчеркиваю, что в основе своей она опять же не уникальна, имеет общероссийский и современный цивилизационный характер.

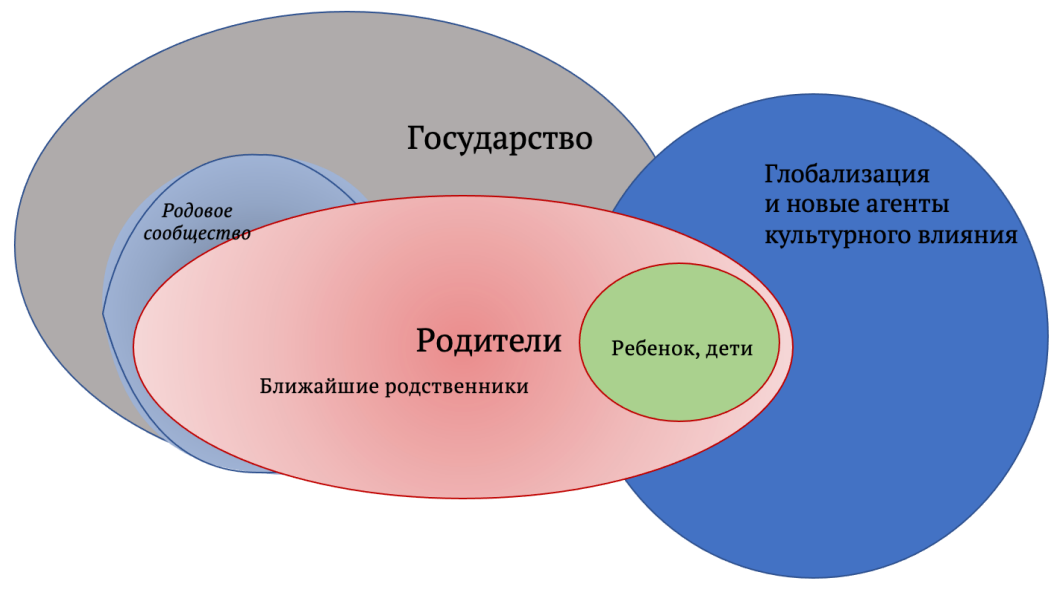

Рис. 3. Место культуры детей в социокультурном окружении в ХХІ в. Fig. 3. The place of children's culture in the socio-cultural environment in the 21st century.

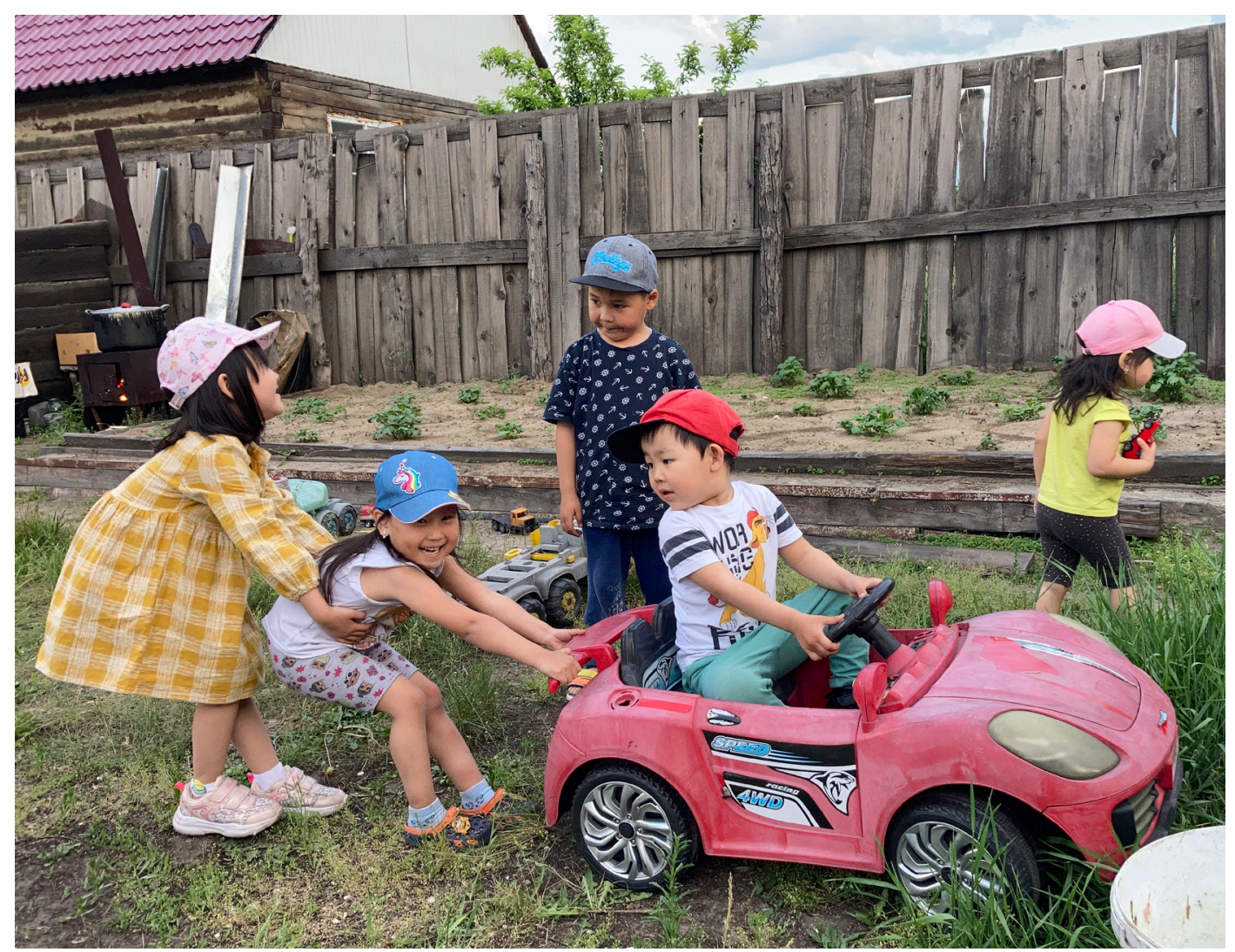

Фото 1. Тувинские дети играют в машинку. г. Кызыл, 2021 г. Фото автора. Photo 1. Children are playing with a toy car. Kyzyl, 2021. Photo by the author. 
Государство уже потеряло свое главенствующую позицию регулятора. Новыми мощнейшими факторами, определяющими особенности культуры детства, выступают теперь вестернизационные тенденции, технологические новации, которые появились с глобализацией. У детей иные игрушки, иные герои (фото 1).

В этих условиях в отношении взрослых к детям появились новые, дополнительные мотивы. Помимо тех категорий взрослых, которые продолжали растить детей в любви и заботе, появились и такие, которые или были недостаточно ответственными или увлеклись избыточной опекой.

Во-первых, современной общей российской тенденцией стал и увеличенный период инфантильности людей (Демиденко, 2018). Ю. В. Олейников называет инфантильными людьми тех, чей уровень психического, социального и нравственного развития не соответствует их реальному возрасту (Олейников, 2007: 23). Они не способны к самоорганизации и самоограничениям, управляется прихотями, свойственным скорее детям. Философ считает, что инфантильность во многом присуща России исторически, в том числе как одно из следствий циклического развития цивилизации с периодами деградации и архаизации (там же: 30-72). Подобная инфантилизация распространилась и в тувинском обществе.

Психологически оставаясь инфантильной, но физически созревая, определенная часть тувинская молодежь становятся родителями и все также продолжают вести безответственный образ жизни. Они не ощущают над собой никакого контроля - ни родового сообщества, ни государства, поскольку оба регулятора потеряли ценность и значимость. Такая молодежь не признает себя родителями, ответственными за своих детей. Именно они в Туве могут оставлять детей в опасности, отказываться от них и даже убивать их, избавляться, при этом ведя нездоровый образ жизни (Монгуш, 2021).

Вот всего лишь небольшая подборка новостей о таких чрезвычайных происшествиях за два последних года - 2020-2021 гг.

\section{3 июля 2020 г., сообщило РИА-Новости, в Туве}

«мама ребенка с сожителем, прихватив ребенка, начала выпивать на берегу реки в местечке АлдыыШынаа Улуг-Хемского района. Мальчика женщина хватилась только вечером, при этом об обстоятельствах случившегося она следствию ничего сказать не смогла из-за сильного опьянения.

“Тело ребенка было обнаружено в водах реки в 500 метрах от места исчезновения. На теле ребенка каких-либо признаков, свидетельствующих о криминальной причине смерти, не выявлено”»1.

В конце прошлого года Туву потрясла одна из самых резонансных историй. В ночь на 6 декабря 2020 г. на территории левобережных дач города Кызыла на улице от обморожения погибла 7-месячная девочка. В причинении смерти по неосторожности обвиняется 49-летняя женщина.

«Выяснилось, что обвиняемая находилась в доме знакомой супружеской пары. Во время совместного распития спиртных напитков между мужем и женой началась ссора, в результате которой стал плакать их ребенок. Пьяная гостья решила забрать малышку к себе домой, и не надев на нее зимнюю одежду, вышла на улицу.

По пути она упала и на том же месте уснула. “Очнувшись через некоторое время, она обнаружила, что девочка замерзла”, - говорится в сообщении СУ СК РФ по Республике Тыва².

Позже в память о погибшей девочке в том же месте была установлена скульптура, создание которой инициировали активные молодые люди - блогеры, объявлявшие для этого сбор денег в Интернете 3

\footnotetext{
${ }^{1}$ Пропавшего в Туве четырехлетнего ребенка нашли мертвым [Электронный ресурс] // РИА-Новости. 2020, 3 июля. URL: https://ria.ru/20200703/1573833562.html (дата обращения: 05.09.2021).

${ }^{2}$ В Туве уголовное дело по факту гибели младенца на морозе передано в суд [Электронный ресурс] // ИА «Туваонлайн». 2021, 9 июня. URL: https://www.tuvaonline.ru/2021/06/09/v-tuve-ugolovnoe-delo-po-faktu-gibelimladenca-na-moroze-peredano-v-sud.html (дата обращения: 05.09.2021).

${ }^{3}$ На Левобережных дачах Кызыла устанавливают скульптуру в память о погибшей из-за безответственности родителей малышки [Электронный ресурс] // ИА «Туваонлайн». 2021, 29 мая. URL: https://www.tuvaonline. ru/2021/05/29/na-levoberezhnyh-dachah-kyzyla-ustanavlivayut-pamyatnik-v-pamyat-o-pogibshey-iz-zabezotvetstvennosti-roditeley-malyshki.html (дата обращения: 05.09.2021).
} 
16 мая 2021 г., 29-летняя жительница поселка Хову-Аксы стала фигуранткой уголовного дела: «около семи часов вечера женщина находилась в нетрезвом состоянии. Она покормила грудью новорожденного сына и заснула с ним, а когда проснулась ребенок был мертв».

23 июля 2021 г., как сообщило ИА «Туваонлайн»,

«в дежурную часть полиции Кызыла поступило сообщение о том, что на ул. Новомостовой левобережного дачного общества обнаружен лежащий на земле грудной ребенок.

Сотрудники полиции установили, что младенца-девочку в возрасте около 8-9 месяцев нашла проходящая мимо женщина. Ребенок был без одежды, на теле имелись ссадины и следы укусов от комаров. Кроме того, у младенца имелись признаки повышенной температуры. ...

В настоящее время сотрудниками полиции проводится комплекс проверочных и розыскных мероприятий по установлению личности законных представителей ребенка»².

Ни угрозы уголовных наказаний, лишения родительских прав, ни общественное порицание, ни призывы чтить народные традиции - так и не помогают. Тувинская общественность не узнает в этих вопиющих случаях своих же соплеменников - матерей, отцов. Фактически этот процесс деградации родительства потерял этническую составляющую. Утеряны тувинские традиционные регуляторы социальной жизни, родительских обязанностей, их ответственности и тувинской культуры здесь нет.

Менее опасной формой инфантилизма молодых родителей стало стремление жить по большей части на пособия от государства, иждивенчество. Особенно важной для тувинцев в этом плане стал материнский капитал - мера государственной поддержки для молодых семей, которая была введена в России с 2007 года и предназначена для единовременной выплаты по рождению или усыновлению второго ребенка. Если сначала условия получения этой выплаты были достаточно жесткие (только на улучшение жилищных условий или образование ребенка), то в последующем список целей расходования увеличился, а сама сумма материнского капитала индексировалась в соответствии с инфляцией. От 250 тыс. в 2007 г. эта сумма до 2021 г. возросла до 483882 руб. на первого ребенка и до 639431,83 на второго ребенка. Эта мера в Туве напрямую, как пишут С. П. Монгуш и В. Т. Ликтан, привела к росту рождаемости населения (Монгуш, Ликтан, 2016), однако породила другие проблемы: увеличение численности населения, проживающего за порогом бедности.

В другой форме отношения родителей-тувинцев к детям, которая получила гипертрофированную форму - гиперопеку, гиперзаботу. Значительная часть тувинцев сделала нормой не только обеспечение ребенка всем необходимым в детстве, но и в последующем взрослении - в поступлении в вуз, в женитьбе, в приобретении жилья, в отправке в армию (или уклонении от обязательной воинской службы). Особенно важным считается приобретение жилья, для чего родители нередко оформляют ипотечные кредиты на себя.

Приведу два типичных примера планирования будущего своим детям у современных тувинцев.

Семья А., индивидуальные предприниматели, проживающие в г. Кызыле, оба в возрасте 33 г., имеют двух детей - дочь и сына. Когда детям исполнилось 6-7 лет, родители открыли на них сберегательные счета с первоначальным вкладом 30000 руб. на каждого и ежегодно пополняют эту сумму. Этот капитал мама и папа планируют нарастить для расходов на образование детей к их 18-летию. Но, помимо этого, родители уже сейчас приобрели для них две благоустроенные квартиры, которые пока сдают в аренду, пока их маленькие хозяева растут.

Женщина Д., мать-одиночка, 56 лет, вырастила одна сына, которому по достижении 15 лет приобрела 1-комнатную квартиру, оформив ее в ипотечный кредит на себя. Он продолжал жить с мамой, причем до своей женитьбы в возрасте 28 лет. Все это время стоимость его квартиры выплачивалась его мамой, пока кредит не был погашен полностью, в том числе при помощи сдачи жилья в аренду. Когда сын женился, то у

\footnotetext{
${ }^{1}$ Следователи Тувы занимаются делом горе-мамаши, задавившей новорожденного сына [Электронный ресурс] // ИА «Туваонлайн». 2021, 23 июня. URL: https:/www.tuvaonline.ru/2021/06/23/sledovateli-tuvy-zanimayutsyadelom-gore-mamashi-zadavivshey-novorozhdennogo-syna.html (дата обращения: 05.09.2021).

${ }^{2}$ В Кызыле нашли брошенного на землю младенца, он был без одежды и покусан комарами [Электронный ресурс] // ИА «Туваонлайн». 2021, 23 июля. URL: https://www.tuvaonline.ru/2021/07/23/v-kyzyle-nashli-broshennogona-zemlyu-mladenca-on-byl-bez-odezhdy-i-pokusan-komarami.html (дата обращения: 05.09.2021).
} 
его невесты тоже оказался маленький домик в так называемом частном секторе, который ей остался после бабушки. После свадьбы родители молодоженов продали и квартирку, и дом, объединили средства и смогли обеспечить молодую семью уже жильем большей площади - 3-комнатной благоустроенной квартирой.

В этом стремлении тувинцев обеспечить детей жильем видится отголосок тувинской традиции, предписывающей дарить новой семье отдельную юрту. Однако, в современных условиях, конечно, такой подход взрослых к поддержке молодежи не способствует их трудовому воспитанию, стремлению быть самостоятельным, обеспечивать себя.

Если говорить о других этнокультурных особенностях такой гиперопеки, то вспоминаются также и свадьбы. Как я уже с коллегой Ш. Б. Майны подчеркивала в исследовании современных тувинских свадеб (Ламажаа, Майны, 2020), этот семейный ритуал перестал быть только праздником новой семьи и считаться обрядом для установления родственных связей между сторонами брачующихся. Сегодня тувинские свадьбы приобрели характер взаимной презентации состоятельности родителей и их родов. Размах торжества, количество гостей и ценность подарков стали показателем финансовых и иных возможностей, которые стало важно подчеркивать, даже бравировать. И хотя в Туве такая свадебная обрядность не доходит до масштабов среднеазиатских свадеб, которые разоряют людей на всю жизнь, тем не менее она тоже приводит к дополнительной закредитованности населения. И самостоятельные молодые люди сегодня все больше предпочитают бюджетные церемонии (просто регистрацию в органах ЗАГС), сами свадьбы откладываются на несколько лет и потом проводятся, когда брачующиеся уже окружены несколькими подрастающими детьми, когда церемонию приходиться организовывать под давлением старшего поколения.

Наличие правила, когда родители обязаны обеспечить детей жильем - домом или квартирой, приводит к тому, что обеспеченные жильем молодые люди считаются более перспективными для заключения брачных союзов. Свое жилье у молодого человека в регионе, где жилищный вопрос стоит чрезвычайно остро, а уровень доходов большинства населения низкий, - сейчас очень важный признак состоятельности. В Туве нет жестких брачных норм и молодежь женится по своим желаниям, однако, влияние родителей, рассматривающих состоятельность «кудагаев» (русифицированная форма тув. разг. слова кудагай 'сват', 'сватушка') - будущих сватов и того, что они могут дать молодоженам, осталось достаточно большим. Так, в 2000 г. новосибирские этносоциологи зафиксировали: 52\% тувинцев считали, что необходимо получить согласие родителей на брак (Гончарова, Савельев, 2004: 2007). И в условиях, когда брак традиционно считался обязательным для каждого тувинца (Seden, 2014), это обстоятельство можно считать важным для поддержания традиционализма в тувинском обществе.

Желание обеспечивать детей не иссякает, даже когда они взрослеют, создают свои семьи и рожают своих детей. Это приводит к тому, что значительное число тувинцев старшего поколения продолжает работать для этого, не выходя на пенсионный отдых. Для многих тувинцев стало нормой работать на детей практически до смерти. При этом, гиперопека естественным образом способствует дальнейшему развитию инфантилизации молодежи. Молодые семьи продолжают рассчитывать на помощь родителей, требовать от них квартиры, машины, различную помощь. В том числе стало нормой привлекать для ухода за маленькими детьми бабушек и дедушек, которые или не работали, или специально для этого оставляли работу. В условиях переполненности детских садов, невозможности отдать ребенка туда, для молодых матерей, которая стремится выйти работать, это может быть единственным выходом.

Представлю кратко вехи жизни одной городской тувинской семьи 3. (муж А., 56 года, жена Б., 55 лет, двое детей - сын С. и дочь Д., соответственно 31 и 28 лет), в которой соединились вместе все вышеотмеченные тенденции.

Б. до встречи с будущим мужем жила в общежитии в г. Кызыле, учась в местном училище. Ее мама работала чабаном и жила в районе, отец умер несколько лет назад. Через некоторое время, когда А. и Б. стали встречаться, то выяснилось, что А. частенько выпивает, но, тем не менее, у него была квартира в Южном районе Кызыла, которую ему купили его родители. Поэтому А. согласилась выйти за него замуж. Свадьбу сыграли скромную, в одной из столовых города.

Дети семьи 3. родились в 1991 и 1993 гг. В лихие 1990-е г. растить детей было очень нелегко, поэтому им помогали бабушки и дедушка. Бабушка-животновод периодически отправляла мясо в город. Правда, муж периодически срывался и уходил в запой, жене приходилось и работать, и поднимать детей, и следить за мужем. Дети росли, больше говоря по-русски, чем по-тувински, потому что учились в русскоязычной школе, 
и требовали к себе больше внимания. Но если девочка была относительно послушной, мальчик оказался без внимания отца и довольно быстро попал в плохую компанию, у него не сложилось с учебой. Он остался жить с родителями, так и не женился, выпивал теперь вместе с отцом, перебивался случайными заработками. Дочь выучилась в местном университете, вышла замуж и мама была рада, что ее избранник имел в перспективе квартиру, которую ему обещала оставить после себя его бабушка. Но пока она здравствовала, молодые сняли квартиру. У них родился сначала один сын, потом второй. Дочь Д. сидела с ними до 1-1,5 лет, потом им удавалось получить место в детском саду, в первый раз по знакомству с заведующей, а во второй раз пришлось собирать деньги на платное место. Для этого также бабушка Б. взялась за дополнительную работу, чтобы помочь им. В остальное время она продолжает работать, оплачивать жизнь сыну, присматривать за мужем (периодически его пролечивая от алкоголизма), помогать материально дочери и внукам. И в ее планах нет выхода на пенсию для отдыха. Она уже начала получать пенсию по возрасту, не отказываясь от работы в бухгалтерии одного учреждения, и пенсия стала хорошим подспорьем всему семейству.

Внуки очень любят гаджеты, много времени проводят за компьютерными играми. Они еще хуже, чем их родители, говорят по-тувински. Не любят поездки в район, не особенно любят национальную кухню, в том числе вареную колбасу свежеразделанного барана - изиг хан, которую так ценит их бабушка. Но баловать внуков хочется. Если совсем крошками они любили игрушки - персонажей западных мультфильмов «Тачки», «Человек-паук», то теперь требуют покупок различных компьютерных игр.

Современные взаимоотношения родителей и детей у тувинцев стали разниться в зависимости от опыта социализации самих родителей, которым пришлось пережить распад СССР, тяжелое первое десятилетия общественного кризиса. Над семьей нет больше тотального контроля государства, нет и такого древнего регулятора как родовое сообщество. В последние годы у тувинцев стали укрепляться связи между родственниками как в форме общих родовых обрядов, проходящих раз в год (Дагылга: тувинские ... , 2021; Ламажаа, 2021a), так и с помощью новых коммуникационных технологий, позволяющих общаться ежедневно в режиме онлайн (Ламажаа, 2021b). Однако, родственники ничего не могут сделать, если кто-то из молодежи сходит с правильного пути и ломает свою жизнь, погружаясь в алкоголизм или совершая преступления.

\section{Заключение}

Если раньше дети для тувинцев были сначала будущими помощниками по хозяйству, потом рассматривались как будущие строители социализма, которых надо было достойно вырастить и выпустить из родительского гнезда в первую очередь на благо обществу, то сегодня отношение у тувинцев к детям амбивалентное.

Они и те существа, которых надо пестовать, холить и лелеять. Они и те, кого надо обеспечивать так долго, сколько хватит сил. А есть такие родители, которые не хотят детей, не заботятся о них должным образом. Дети - это не только любимые чада. Для тех, кто живет сегодняшним днем, от зарплаты до зарплаты, от пособия к пособию, дети - источник таких государственных выплат, материнского капитала. Для других родителей дети - существа, требующие все больше и больше вложений, заботы, которая не заканчивается с их взрослением.

Все эти тенденции универсальны и присущи не только тувинцам. Этническая специфика традиционных взаимоотношений была связана с общей системой этнокультурных традиций. Сегодня все то, что происходит негативного в этой сфере связано именно с утратой этнокультурных регуляторов, важность которых я и постаралась показать. Этнокультурная ценностей детей для тувинцев уругдарыг - возможно, скорее осталась идеальным, утраченным образом прошлого.

Но тема children's studies в тувиноведении имеет еще массу нюансов, которые было бы интересно раскрыть, изучить. В том числе и уменьшение роли мужчин в семейной жизни тувинцев, о чем еще в начале 2000-х гг. написал Ш. Степанофф (Степанофф, 2009; также об этом: Монгуш, 2021). К числу перспективных исследований культуры детства также можно назвать исследование «детских голосов», поскольку до сих пор в науке представлено только представление детей глазами и устами взрослых.

\section{СПИСОК ЛИТЕРАТУРЫ}

Андреева, А. В. (2015) Культура репродуктивного поведения в кочевой культуре народов Восточной Сибири : автореф. дисс. ... канд. культурологии. Улан-Удэ. 23 с. 
Аранчын, Ю. Л. (1982) Исторический путь тувинского народа к социализму. Новосибирск : Наука. 339 с.

Арьес, Ф. (1999) Ребенок и семейная жизнь при Старом порядке : пер. с фр. Екатеринбург : Изд-во Уральского университета. 416 с.

Ашенова, К. К. (2018) Советское детство: повседневная жизнь детей Омска (1961-1980 гг.) : автореф. дисс. ... канд. ист. н. Тюмень. 28 с.

Вайнштейн, С. И. (1991) Мир кочевников центра Азии. М. : Наука. 299 с.

Волков, Г. Н., Салчак, К. Б., Шаалы А. С. (2009) Этнопедагогика тувинского народа. Кызыл : Изд.-полигр. комплекс «Билиг». 212 с.

Гончарова, Г. С., Савельев, Л. Я. (2004) Семейно-брачные отношения у народов Сибири: проблемы, тенденции, перспективы. Новосибирск : Нонпарель. 288 с.

Дагылга: тувинские обряды освящения в XXI веке (2021) / под ред. Ч. К. Ламажаа и Н. Д. Сувандии. Кызыл : б. и. 188 с.

Данчай-оол, А. А., Даваа, Е. К. (2021) Социально-культурный аспект конфликта поколений в тувинском обществе: современность и перспективы // Философская мысль. № 1. С. 11-23. DOI: https://www.doi.org/10.25136/24098728.2021.1.34315

Демиденко, А. С. (2018) Социальная инфантильность российской молодежи: специфика научного дискурса // Историческая и социально-образовательная мысль. Том. 10. № 3-1. С. 143-149.

Доржу, 3. Ю., Корчевская, Е. А. (2015) Традиции тувинцев в отношении детей-сирот и детей, оставшихся без попечения родителей // Вестник ТГПУ. № 9. С. 270-278.

Дыртык-оол, М. О. (2015) Мир детства у тувинцев: культурологический обзор антологии «Урянхай. Тыва дептер» (тувинская тетрадь) // Научно-методический электронный журнал Концепт. Т. 13. С. 1946-1950.

Дыртык-оол, М. О. (2018) Трансформация инкультурации детей в условиях седентаризации тувинского общества // Вестник Таджикского национального университета. № 6. С. 140-146.

Дьяконова, В. П. (1988) Детство в традиционной культуре тувинцев и теленгитов // Традиционное воспитание детей у народов Сибири / отв. ред. И. С. Кон, Ч. М. Таксами. Л. : Наука. 251 с. С. 152-185.

Ежова, О. Ф. (2019) Игровая культура детей Тувы: борьба хуреш и этническая социализация мальчиков // Традиционная культура. Т. 20. № 2. C. 63-71. DOI: https://www.doi.org/10.26158/TK.2019.20.2.005

Иконникова, С. Н. (2018) «Защитный пояс» культуры и стратегии отношения к детству // Вестник СПбГИК. № 4. C. 56-59. DOI: https://www.doi.org/10.30725/2619-0303-2018-4-56-59

Иргит, Е. Л. (2013) Роль отца в формировании личности детей // Вестник Тувинского государственного университета. № 1. Социальные и гуманитарные науки. С. 53-58.

Кара-оол, Л. С. (2019) Лексика родильного обряда в тувинском языке // Oriental Studies. T. 12 . № 6 (46). С. 1145-1155. DOI: https://www.doi.org/10.22162/2619-0990-2019-46-6-1145-1155

Кара-оол, Ч. А. (2013) Детский музыкальный фольклор тывинцев // Известия Алтайского государственного университета. № 2-2. С. 188-190.

Кара-оол, Ч. А. (2014) Пестушки в детском фольклоре тувинцев // Вестник Казанского государственного университета культуры и искусств. № 2. С. 45-47.

Караоол, Ч. А. (2015а) Детская игровая культура у тувинцев // Известия Алтайского государственного университета. № 4-1 (88). С. 144-148.

Кара-оол, Ч. К. (2015b) Детский фольклор как механизм социализации ребенка в традиционной культуре тувинцев (конец XIX - начало XXI вв.) : дисс. ... канд. ист. н. Улан-Удэ. 135 с.

Кара-оол, Ч. А. (2015с) Материнская поэзия в детском фольклоре тувинцев // Новые исследования Тувы. № 2. C. 61-68.

Кенин-Лопсан, М. Б. (2006) Традиционная культура тувинцев : пер. с тув. Кызыл : Тувинское книжное издательство. 232 с.

Кенин-Лопсан, М. Б. (2017) Тыва чаңчыл [Тувинские традиции]. Кызыл : Тувинское книжное издательство. 232 с. (На тув. яз.)

Кисель, В. А. (2016) Мир детей в столице Тувы // Новые исследования Тувы. № 1. С. 38-63.

Комарова, Г. А. (2014) Этнография детства. Междисциплинарные исследования. 2-е изд. М. : ИЭА РАН. 160 с.

Кон, И. С. (1988) Ребенок и общество. (Историко-этнографическая перспектива). М. : Наука. 269 с. 
Конструируя детское: филология, история, антропология (2011) / под ред. М. Р. Балиной, В. Г. Безрогова, С. Г. Маслинской, К. А. Маслинского, М. В. Тендряковой, С. Шеридана. М.; СПб. : Азимут ; Нестор-История. 552 с.

Корчевская, Е. А. (2016) Об устройстве в Туве детей-сирот и детей, оставшихся без попечения родителей // Проблемы социально-экономического развития Сибири. № 1. С. 70-74.

Курбатский, Г. Н. (2001) Тувинцы в своем фольклоре (историко-этнографические аспекты тувинского фольклора). Кызыл : Тувинское книжное издательство. 464 с.

Кужугет, А. К. (2019) Тувинская семья: традиции и трансформации // Ученые записки. Тувинский институт гуманитарных и прикладных социально-экономических исследований при Правительстве Республики Тыва / отв. ред. Б. А. Донгак.; сост. Л. С. Мижит. Кызыл: б. и. 436 с. С. 232-245.

Куприянов, Б. В. (2018) Внешкольная повседневность советских школьников: сюжеты и структуры // Поволжский педагогический поиск. № 4. С. 28-36. DOI: https://www.doi.org/10.33065/2307-1052-2018-4-26-28-36

Куулар, С.-С. В. (2019) Ценностные ориентации тувинской семьи как педагогическая проблема // Вестник Тувинского государственного университета. № 4 Педагогические науки. № 2 (47). С. 11-17.

Ламажаа, Ч. К. (2011) Тува между прошлым и будущим. 2-е изд. СПб. : Алетейя. 368 с.

Ламажаа, Ч. К. (2013) Архаизация общества. Тувинский феномен. М. : Книжный дом «Либроком». 272 с.

Ламажаа, Ч. К. (2015) Ребенок в тувинской культуре // Новые исследования Тувы. № 1. С. $79-89$.

Ламажаa, Ч. К., Майны, Ш. Б. (2020) Свадебная обрядность тувинцев: от установления семейных связей до социальной презентации // Oriental Studies. № 13(2). C. 405-421. DOI: https://doi.org/10.22162/2619-0990-2020-482-405-421

Ламажаа, Ч. К. (2021a) Социальная культура тувинцев и онлайн-пространство // Новые исследования Тувы. № 2. C. 115-129. DOI: https://www.doi.org/10.25178/nit.2021.2.10

Ламажаa, Ч. К. (2021b) Тувинские обряды дагылга в XXI веке // Этнографическое обозрение. № 2. С. $125-143$. DOI: https://doi.org/10.31857/S086954150014811-2

Ликтан, В. Т., Монгуш, С. П. (2021) Эстетическое воспитание как актуальная проблема тувинских школьников // Инновации. Наука. Образование. № 29. С. 865-869.

Мирошниченко, В. В., Донгак, А. А. (2020) Использование тувинских традиций как условие социализации младших школьников // Вопросы педагогики. № 11-1. С. 152-155.

Молодежь Тувы. Социальный портрет (1988) / 3. В. Анайбан и др. Новосибирск : Наука, Сибирское отделение. 194 c.

Монгуш, А. М. (2021) Особенности трансформации роли мужчины в тувинском обществе // Известия Иркутского государственного университета. Серия Геоархеология. Этнология. Антропология. Т. 36. C. 37-49. DOI: https:// doi.org/10.26516/2227-2380.2021.36.37

Монгуш, В. Ч. (2006) История образования в Тувинской Народной Республике (1921-1944 гг.) : автореф.... канд. ист. н. М. 24 с.

Монгуш, С. П., Ликтан В. Т. (2016) Динамика рождаемости и социального положения населения Тувы // Перспективы науки. № 12. С. 49-53.

Олейников, Ю. В. (2007) Инфантильный социум? (аналитическое эссе). М. : Издательство Российского государственного социального университета. 172 с.

Омарова, П. О., Гасанова, 3. 3. (2008) Семья как институт социализации и воспитания // Сибирский педагогический журнал. № 4. С. 173-185.

Ооржак, С. С., Бавуу-Сюрюн, М. В. (2020) Лексика обрядов по защите жизни детей в тувинском языке // Новые исследования Тувы. № 1. C. 96-103. DOI: https://www.doi.org/10.25178/nit.2020.1.8

Потапов, Л. П. (1969) Очерки народного быта тувинцев. М. : Наука. 402 с.

Разинкова, О. И. (2021) Феномен детства в трансформирующемся российском обществе (социальнофилософский анализ) : автореф. дисс.... к-та филос. н. М. 23 с.

Ромашова, М. В. (2013) Дети и феномен детства в отечественной истории: новейшие исследования, дискуссионные площадки, события // Вестник Пермского университета. История. Вып. 2. С. 108-116.

Салчак, Б. В. (2009) Конструирование образовательной среды дошкольного учреждения как условие воспитания национального самосознания детей : автореф. дисс. ... канд. пед. н. Екатеринбург. 22 с. 
Салчак, К. Б., Салчак, Л. П. (1984) Развитие тувинской народной педагогики. Кызыл : Тувинское книжное издательство. 28 с.

Салчак, К. Б., Салчак Л. П. (2016) Тыва улусчу педагогиканың хөгжүлдези = Развитие тувинской народной педагогики. Кызыл : Национал школа хөгжүдер ин-т. 227 с.

Сальникова, А. А. (2007) Российское детство в XX веке: История, теория и практика исследования. Казань: Казанский государственный университет им. В. И. Ульянова-Ленина. 256 с.

Степанофф, Ш. (2009) Метаморфозы родства у тувинцев // Этнографические исследования. № 4. С. $129-145$.

Сувандии, Н. Д. (2011) Тувинская антропонимия. Кызыл : РИО ТувГУ. 207 с.

Сундуй, Г. Д. (2009) Мир детства кочевой Азии: опыт духовно-нравственного воспитания. Кызыл : Институт развития национальной школы. 168 с.

Сундуй, Г. Д. (2015) Родовое сообщество как гарант защиты детства (на материале Республики Тыва) // Вестник Красноярского государственного педагогического университета им. В. П. Астафьева. № 1. С. 26-30.

Традиционное воспитание детей у народов Сибири (1988) / отв. ред. И. С. Кон, Ч. М. Таксами. Л. : Наука. 251 с.

Хурен-оол, С. Х. (2018) Трудовое воспитание детей в тувинской семье // Сибирский педагогический журнал. № 2. С. 66-71.

Чамзырын, Е. Т. (2013) Детская литература в период Тувинской Народной Республики // История тувинской литературы / отв. ред. К. А. Бичелдей. Новосибирск : Изд-во СО РАН. 266 с. С. 206-218.

Юша, Ж. М. (2006) Обряды детского цикла у тувинцев: традиции и современность // Гуманитарные науки в Сибири. № 3. С. 111-115.

Юша, Ж. М. (2018) Фольклор и обряд тувинцев Китая в начале XXI века. Структура. Семантика. Прагматика. Новосибирск : Наука. 400 с.

Seden, A. V. (2014) Gender-based approach to the preparation of young people of Tuva for family life // Journal of Siberian Federal University. Humanities and Social sciences. Vol. 7, no. 11. Pp. 1927-1939.

Дата поступления: 20.08.2021 г.

\section{REFERENCES}

Andreeva, A. V. (2015) Kul'tura reproduktivnogo povedeniia v kochevoi kul'ture narodov Vostochnoi Sibiri [The culture of reproductive behavior in the nomadic culture of the peoples of Eastern Siberia] : Abstract of the Diss. ... Candidate of Culturology. Ulan-Ude. 23 p. (In Russ.).

Aranchyn, Yu. L. (1982) Istoricheskii put' tuvinskogo naroda $k$ sotsializmu [The historical path of the Tuvan people to socialism]. Novosibirsk, Nauka Publ. 337 p. (In Russ.).

Ariès, Ph. (1999) Rebenok i semeinaia zhizn' pri Starom poriadke [The child and family life in the Ancien Régime] / transl. from Fr. Ekaterinburg, Publishing House of the Ural University. 416 p. (In Russ.).

Ashenova, K. K. (2018) Sovetskoe detstvo: povsednevnaia zhizn' detei Omska (1961-1980 gg.) [Soviet childhood: Everyday life of Omsk children (1961-1980)] : Abstract of the Diss.... Candidate of History. Tyumen. 28 p. (In Russ.).

Weinstein, S. I. (1991) Mir kochevnikov tsentra Azii [The world of nomads of the center of Asia]. Moscow, Nauka Publ. 296 p. (In Russ.).

Volkov, G. N., Salchak, K. B. and Shaaly, A. S. (2009) Etnopedagogika tuvinskogo naroda [The ethnopedagogy of the Tuvan people]. Kyzyl, Tyvapoligraf Publ. 212 p. (In Russ.).

Goncharova, G. S. and Saveliev, L. Ia. (2004) Semeino-brachnye otnosheniia u narodov Sibiri: problemy, tendentsii, perspektivy [Family-marriage relations among the peoples of Siberia: Problems, trends, and prospects]. Novosibirsk, Nonparel’ Publ. 288 p. (In Russ.).

Dagylga: tuvinskie obriady osviashcheniia v XXI veke [Dagylga: Tuvan rites of consecration in the 21st century] (2021) / ed. by Ch. K. Lamazhaa and N. D. Suvandii. Kyzyl, s. n. 188 p. (In Russ.).

Danchai-ool, A. A. and Davaa, E. K. (2021) Sotsial'no-kul'turnyi aspekt konflikta pokolenii v tuvinskom obshchestve: sovremennost' i perspektivy [Sociocultural aspect of conflict of generations in the Tuvan society: Modernity and prospects]. Philosophical Thought, no. 1, pp. 11-23. (In Russ.). DOI: https://doi.org/10.25136/2409-8728.2021.1.34315

Demidenko, A. S. (2018) Sotsial'naia infantil'nost' rossiiskoi molodezhi: spetsifika nauchnogo diskursa [Social infantility of Russian youth: Specificity of scientific discourse]. Istoricheskaia i sotsial'no-obrazovatel'naia mysl', vol. 10, no. 3-1, pp. 143-149. (In Russ.). 
Dorzhu, Z. Yu. and Korchevskaia, E. A. (2015) Traditsii tuvintsev v otnoshenii detei-sirot i detei, ostavshikhsia bez popecheniia roditelei [Traditions of Tuvans concerning orphaned children and children without parental support]. Vestnik TGPU, no. 9, pp. 270-278. (In Russ.).

Dyrtyk-ool, M. O. (2015) Mir detstva u tuvintsev: kul'turologicheskii obzor antologii «Uriankhai. Tyva depter» (tuvinskaia tetrad') [The world of childhood among Tuvans: A culturological review of the anthology "Uriankhai. Tuva depter” (Tuvan notebook)]. Nauchno-metodicheskii elektronnyi zhurnal “Kontsept”. vol. 13, pp. 1946-1950. (In Russ.).

Dyrtyk-ool, M. O. (2018) Transformatsiia inkul'turatsii detei v usloviiakh sedentarizatsii tuvinskogo obshchestva [Transformation of the inculturation of children in the conditions of sedentarization of Tuvan society]. Vestnik Tadzhikskogo natsional'nogo universiteta, no. 6, pp. 140-146. (In Russ.).

Diakonova, V. P. (1988) Detstvo v traditsionnoi kul'ture tuvintsev i telengitov [Childhood in the traditional culture of Tuvans and Telengits]. In: Traditsionnoe vospitanie detei u narodov Sibiri [Traditional upbringing of children among the peoples of Siberia] / ed. by I. S. Kon and Ch. M. Taksami. Leningrad, Nauka Publ. 251 p. Pp. 152-185. (In Russ.).

Ezhova, O. F. (2019) Igrovaia kul'tura detei Tuvy: bor'ba khuresh i etnicheskaia sotsializatsiia mal'chikov [The culture of Tuvan children's play: Khuresh wrestling and the ethnic socialization of boys]. Traditional culture, vol. 20, no. 2, pp. 63-71. (In Russ.). DOI: https://doi.org/10.26158/TK.2019.20.2.005

Ikonnikova, S. N. (2018) «Zashchitnyi poias» kul'tury i strategii otnosheniia k detstvu ["Protective belt” of culture and strategy of attitude to childhood]. Vestnik SPbGIK, no. 4, pp. 56-59. (In Russ.). DOI: https://doi.org/10.30725/2619-03032018-4-56-59

Irgit, E. L. (2013) Rol' ottsa v formirovanii lichnosti detei [Father's role in children's personality formation]. Vestnik Tuvinskogo gosudarstvennogo universiteta. Sotsial'nye i gumanitarnye nauki, no. 1, pp. 53-58. (In Russ.).

Kara-ool, L. S. (2019) Leksika rodil'nogo obriada v tuvinskom iazyke [Tuvan vocabulary of birth rites]. Oriental Studies, vol. 12, no. 6 (46), pp. 1145-1155. (In Russ.). DOI: https://doi.org/10.22162/2619-0990-2019-46-6-1145-1155

Kara-ool, Ch. A. (2013) Detskii muzykal'nyi fol'klor tyvintsev [Children's musical folklore of Tuvans]. Izvestiia Altaiskogo gosudarstvennogo universiteta, no. 2-2, pp. 188-190. (In Russ.).

Kara-ool, Ch. A. (2014) Pestushki v detskom fol'klore tuvintsev [Pestushkas (nursing songs) in children's folklore of Tuvans]. Vestnik Kazanskogo gosudarstvennogo universiteta kul'tury i iskusstva, no. 2, pp. 45-47. (In Russ.).

Karaool, Ch. A. (2015a) Detskaia igrovaia kul'tura u tuvintsev [Children's play culture among Tuvans]. Izvestiia Altaiskogo gosudarstvennogo universiteta, no. 4-1 (88), pp. 144-148. (In Russ.).

Kara-ool, Ch. A. (2015b) Detskii fol'klor kak mekhanizm sotsializatsii rebenka $v$ traditsionnoi kul'ture tuvintsev (konets $X I X-$ nachalo XXI vv.) [Children's folklore as a mechanism of socialization of a child in the traditional Tuvan culture (the late 19th - early 21st c.)] : Diss.... Candidate of History. Ulan-Ude. 135 p. (In Russ.).

Kara-ool, Ch. A. (2015c) Materinskaia poeziia v detskom fol'klore tuvintsev [Mother poetry in children's folklore of Tuvans]. New Research of Tuva, no. 2, pp. 61-68. (In Russ.).

Kenin-Lopsan, M. B. (2006) Traditsionnaia kul'tura tuvintsev [Traditional culture of Tuvans]. Kyzyl, Tuvan Book Publisher. 232 p. (In Russ.).

Kenin-Lopsan, M. B. (2017) Tyva changchyl [Tuvan traditions]. Kyzyl, Tuvan Book Publisher. 232 p. (In Tuv.).

Kisel', V. A. (2016) Mir detei v stolitse Tuvy [The world of children in the capital of Tuva]. New Research of Tuva, no. 1, pp. 38-63. (In Russ.).

Komarova, G. A. (2014) Etnografiia detstva. Mezhdistsiplinarnye issledovaniia [Ethnography of childhood. Interdisciplinary research]. 2nd ed. Moscow, Institute of Ethnology and Anthropology RAS. 160 p. (In Russ.).

Kon, I. S. (1988) Rebenok i obshchestvo (istoriko-etnograficheskaia perspektiva) [The child and society (Historical and ethnographic perspective)]. Moscow, Nauka Publ. 269 p. (In Russ.).

Konstruiruia detskoe: filologiia, istoriia, antropologiia [Designing children's: Philology, history, anthropology] (2011) / ed. by M. R. Balina, V. G. Bezrogov, S. G. Maslinskaia, K. A. Maslinskii, M. V. Tendriakova and S. Sheridan. Moscow ; St. Petersburg, Azimut Publ. ; Nestor-Istoriia Publ. 552 p. (In Russ.).

Korchevskaia, E. A. (2016) Ob ustroistve v Tuve detei-sirot i detei, ostavshikhsia bez popecheniia roditelei [On the placement of orphans and children without parental support in Tuva]. Problemy sotsial'no-ekonomicheskogo razvitiia Sibiri, no. 1, pp. 70-74. (In Russ.).

Kurbatskii, G. N. (2001) Tuvintsy v svoem fol'klore (istoriko-etnograficheskie aspekty tuvinskogo fol'klora) [Tuvans in their folklore (Historical and ethnographic aspects of Tuvan folklore)]. Kyzyl, Tuvan Book Publisher. 464 p. (In Russ.). 
Kuzhuget, A. K. (2019) Tuvinskaia sem'ia: traditsii i transformatsii [Tuvan family: Traditions and transformations]. In: Uchenye zapiski. Tuvinskii institut gumanitarnykh i prikladnykh sotsial'no-ekonomicheskikh issledovanii pri Pravitel'stve Respubliki Tyva [Scientific notes. Tuvan Institute of Humanities and Applied Social and Economic Research under the Government of the Republic of Tuva] / ed. by B. A. Dongak ; comp. by L. S. Mizhit. Kyzyl, s. n. 436 p. Pp. 232-245. (In Russ.).

Kupriyanov, B. V. (2018) Vneshkol'naia povsednevnost' sovetskikh shkol'nikov: siuzhety i struktury [Extracurricular daily life of Soviet schoolchildren in plots and structures]. Povolzhskii pedagogicheskii poisk, no. 4, pp. 28-36. (In Russ.). DOI: https://doi.org/10.33065/2307-1052-2018-4-26-28-36

Kuular, S.-S. V. (2019) Tsennostnye orientatsii tuvinskoi sem’i kak pedagogicheskaia problema [Value orientations of the Tuvan family as a pedagogical subject]. Vestnik Tuvinskogo gosudarstvennogo universiteta, issue 4: Pedagogicheskie nauki, no. 2 (47), pp. 11-17. (In Russ.).

Lamazhaa, Ch. K. (2011) Tuva mezhdu proshlym i budushchim [Tuva between the past and future]. St. Petersburg, Aletheia Publ. 368 p. (In Russ.).

Lamazhaa, Ch. K. (2013) Arkhaizatsiia obshchestva. Tuvinskii fenomen [Archaization of the society. Tuvan phenomenon]. Moscow, Knizhnyi dom “Librokom”. 272 p. (In Russ.).

Lamazhaa, Ch. K. (2015) Rebenok v tuvinskoi kul'ture [A child in the Tuvan culture]. New Research of Tuva, no. 1, pp. 79-89. (In Russ.).

Lamazhaa, Ch. K. (2021a) Sotsial'naia kul'tura tuvintsev i onlain-prostranstvo [Social culture of Tuvans and online space]. New Research of Tuva, no. 2, pp. 115-129. (In Russ.). DOI: https://doi.org/10.25178/nit.2021.2.10

Lamazhaa, Ch. K. (2021b) Tuvinskie obriady dagylga v XXI veke [Tuvan rites dagylga in the 21st century]. Etnograficheskoe obozrenie, no. 2, pp. 125-143. (In Russ.). DOI: https://doi.org/10.31857/S086954150014811-2

Lamazhaa, Ch. K. and Mainy, Sh. B. (2020) Svadebnaia obriadnost' tuvintsev: ot ustanovleniia semeinykh sviazei do sotsial'noi prezentatsii [Tuvan wedding rites: From establishment of family ties to social presentation]. Oriental Studies, no. 13 (2), pp. 405-421. (In Russ.). DOI: https://doi.org/10.22162/2619-0990-2020-48-2-405-421

Liktan, V. T. and Mongush, S. P. (2021) Esteticheskoe vospitanie kak aktual'naia problema tuvinskikh shkol'nikov [Aesthetic education as an actual problem of Tuvan schoolchildren]. Innovatsii. Nauka. Obrazovanie, no. 29, pp. 865-869. (In Russ.).

Miroshnichenko, V. V. and Dongak, A. A. (2020) Ispol'zovanie tuvinskikh traditsii kak uslovie sotsializatsii mladshikh shkol'nikov [The use of Tuvan traditions as a condition for the socialization of younger schoolchildren]. Voprosy pedagogiki, no. 11-1, pp. 152-155. (In Russ.).

Molodezh' Tuvy. Sotsial'nyi portret [The youth of Tuva: A social portrait] (1988) / ed. by Yu. L. Aranchyn et al. Novosibirsk, Nauka Publ. 194 p. (In Russ.).

Mongush, A. M. (2021) Osobennosti transformatsii roli muzhchiny v tuvinskom obshchestve [Transformation features of the role of men in Tuvan society]. Bulletin of the Irkutsk State University. Geoarchaeology, Ethnology, and Anthropology Series, vol. 36, pp. 37-49. (In Russ.). DOI: https://doi.org/10.26516/2227-2380.2021.36.37

Mongush, V. Ch. (2006) Istoriia obrazovaniia v Tuvinskoi Narodnoi Respublike (1921-1944 gg.) [History of education in the Tuvan People's Republic (1921-1944)]: Abstract of the Diss.... Candidate of History. Moscow. 24 p. (In Russ.).

Mongush, S. P. and Liktan V. T. (2016) Dinamika rozhdaemosti i sotsial'nogo polozheniia naseleniia Tuvy [Dynamics of fertility and social status of the population of Tuva]. Perspektivy nauki, no. 12, pp. 49-53. (In Russ.).

Oleinikov, Yu. V. (2007) Infantil'nyi sotsium? (analiticheskoe esse) [Infantile society? (An analytical essay)]. Moscow, Russian State Social University Publ. 172 p. (In Russ.).

Omarova, P. O. and Gasanova, Z. Z. (2008) Sem'ia kak institut sotsializatsii i vospitaniia [Family as an institution of socialization and upbringing]. Sibirskii pedagogicheskii zhurnal, no. 4, pp. 173-185. (In Russ.).

Oorzhak, S. S. and Bavuu-Surun, M. V. (2020) Leksika obriadov po zashchite zhizni detei v tuvinskom iazyke [The vocabulary of protecting children's lives in Tuvan language]. New Research of Tuva, no. 1, pp. 96-103. (In Russ.). DOI: https://doi.org/10.25178/nit.2020.1.8

Potapov, L. P. (1969) Ocherki narodnogo byta tuvintsev [The Tuvans: Sketches of the folk lifestyle and related household activities]. Moscow, Nauka Publ. 402 p. (In Russ.).

Razinkova, O. I. (2021) Fenomen detstva $v$ transformiruiushchemsia rossiiskom obshchestve (sotsial'no-filosofskii analiz) [The phenomenon of childhood in the transforming Russian society (A socio-philosophical analysis)] : Abstract of the Diss.... Candidate of Philosophy. Moscow. 23 p. (In Russ.). 
Romashova, M. V. (2013) Deti i fenomen detstva v otechestvennoi istorii: noveishie issledovaniia, diskussionnye ploshchadki, sobytiia [Children and the phenomenon of childhood in Russian history: The latest research, discussion platforms, events]. Vestnik Permskogo universiteta. Istoriia, issue 2, pp. 108-116. (In Russ.).

Salchak, B. V. (2009) Konstruirovanie obrazovatel'noi sredy doshkol'nogo uchrezhdeniia kak uslovie vospitaniia natsional'nogo samosoznaniia detei [Designing the educational environment of a preschool institution as a condition for the development of children's national identity]: Abstract of the Diss.... Candidate of Pedagogy. Ekaterinburg. 22 p. (In Russ.).

Salchak, K. B. and Salchak, L. P. (1984) Razvitie tuvinskoi narodnoi pedagogiki [Development of Tuvan folk pedagogy]. Kyzyl, Tuvan Book Publisher. 28 p. (In Russ.).

Salchak, K. B. and Salchak, L. P. (2016) Tyva uluschu pedagogikanyng khögzhüldezi = Razvitie tuvinskoi narodnoi pedagogiki [Development of Tuvan folk pedagogy]. Kyzyl, Natsional shkola khögzhüder in-t. 227 p. (In Tuv. and Russ.).

Salnikova, A. A. (2007) Rossiiskoe detstvo v XX veke: Istoriia, teoriia i praktika issledovaniia [Russian childhood in the 20th century: History, theory and practice of research]. Kazan, V. I. Ulyanov-Lenin Kazan State University. 256 p. (In Russ.).

Stépanoff, Ch. (2009) Metamorfozy rodstva u tuvintsev [Metamorphoses of kinship among Tuvans]. Etnograficheskoe obozrenie, no. 4, pp. 129-145. (In Russ.).

Suvandii, N. D. (2011) Tuvinskaia antroponimiia [Tuvan anthroponymy]. Kyzyl, Editorial and Publishing Department at Tuvan State University. 207 p. (In Russ.).

Sundui, G. D. (2009) Mir detstva kochevoi Azii: opyt dukhovno-nravstvennogo vospitaniia [The world of nomadic Asia's childhood: The experience of spiritual and moral education]. Kyzyl, The National School Development Institute. 168 p. (In Russ.)

Sundui, G. D. (2015) Rodovoe soobshchestvo kak garant zashchity detstva (na materiale Respubliki Tyva) [The tribal community as a pillar of the protection of childhood (Based on the material of the Republic of Tuva)]. Vestnik Krasnoiarskogo gosudarstvennogo pedagogicheskogo universiteta im. V. P. Astaf'eva, no. 1, pp. 26-30. (In Russ.).

Traditsionnoe vospitanie detei u narodov Sibiri [Traditional upbringing of children among the peoples of Siberia] (1988) / ed. by I. S. Kon and Ch. M. Taksami. Leningrad, Nauka Publ. 251 p. (In Russ.).

Khuren-ool, S. Kh. (2018) Trudovoe vospitanie detei v tuvinskoi sem'e [Labour education of children in Tuvan family]. Sibirskii pedagogicheskii zhurnal, no. 2, pp. 66-71. (In Russ.).

Chamzyryn, E. T. (2013) Detskaia literatura v period Tuvinskoi Narodnoi Respubliki [Children's literature in the period of the Tuvan People's Republic]. In: Istoriia tuvinskoi literatury [A history of Tuvan literature] / ed. by K. A. Bicheldey. Novosibirsk, Publishing House of the Siberian Branch of the RAS. 266 p. Pp. 206-218. (In Russ.).

Yusha, Zh. M. (2006) Obriady detskogo tsikla u tuvintsev: traditsii i sovremennost' [Ceremonial rites of children's cycle among Tuvans: Traditions and contemporaneity]. Gumanitarnye nauki v Sibiri, no. 3, pp. 111-115. (In Russ.).

Yusha, Zh. M. (2018) Fol'klor i obriad tuvintsev Kitaia v nachale XXI veka. Struktura. Semantika. Pragmatika [Folklore and ritual of China's Tuvans in the early 21st century: Structure, semantics, pragmatics]. Novosibirsk, Nauka Publ. 400 p. (In Russ.).

Seden, A. V. (2014) Gender-based approach to the preparation of young people of Tuva for family life. Journal of Siberian Federal University. Humanities and Social sciences, vol. 7, no. 11, pp. 1927-1939.

Submission date: 20.08 .2021 . 